\title{
Research Paper: \\ The Protective Effect of Nortriptyline Against Gastric Lesions Induced by Indomethacin and Cold-shock Stress in Rats
}

Mohammad Javad Khoshnoud ${ }^{1,2} \mathbb{D}$, Majid Keshavarzi ${ }^{2}$, Neda Mokhtari², Amirhossein Sakhteman ${ }^{3}$, Amin Derakhshanfar ${ }^{4}$, Marzieh Rashedinia $^{2,5^{*}} \mathbb{D}^{\mathbb{D}}$

1. Food and Supplements Research Center, Shiraz University of Medical Sciences, Shiraz, Iran.

2. Department of Pharmacology Toxicology, School of Pharmacy, Shiraz University of Medical Sciences, Shiraz, Iran.

3. Department of Medicinal Chemistry, School of Pharmacy, Shiraz University of Medical Sciences, Shiraz, Iran.

4. Diagnostic Laboratory Sciences and Technology Research Center, School of Paramedical Sciences, Shiraz University of Medical Sciences, Shiraz, Iran.

5. Medicinal Plants Processing Research Center, Shiraz University of Medical Sciences, Shiraz, Iran.

\begin{tabular}{|l|l|}
$\begin{array}{l}\text { Use vourdevice to san } \\
\text { and read the artice online }\end{array}$ & $\begin{array}{l}\text { How to cite this paper Khoshnoud MJ, Keshavarzi M, Mokhtari N, Sakhteman A, Derakhshanfar A, Rashedinia M. The Pro- } \\
\text { tective Effect of Nortriptyline Against Gastric Lesions Induced by Indomethacin and Cold-shock Stress in Rats. Iranian Journal } \\
\text { of Toxicology. 2020; 14(3):155-164. http://dx.doi.org/10.32598/ijt.14.3.649.1 }\end{array}$ \\
doj $\mathbf{h t t p : / / d x . d o i . o r g / 1 0 . 3 2 5 9 8 / i j t . 1 4 . 3 . 6 4 9 . 1 ~}$
\end{tabular}

\section{(1) (8)}

Article info:

Received: 08 Jan 2020

Accepted: 07 Jun 2020

Online Published: 01 Jul 2020

* Corresponding author:

Marzieh Rashedinia, PhD.

Address: Department of Pharmacol-

ogy Toxicology, School of Pharmacy,

Shiraz University of Medical Sciences,

Shiraz, Iran.

E-mail: rashedinia@sums.ac.ir

\section{ABSTRACT}

Background: Gastric ulcer is among the most serious stomach disorder universally. Several effective drugs are employed in the management of this disease, although there have been adverse effects in some cases. The aim of this study was to investigate the effect of nortriptyline to protect against gastric lesions, induced by indomethacin or cold-stress in rats.

Methods: Gastric lesions were induced by oral indomethacin $(30 \mathrm{mg} / \mathrm{kg})$ or cold-shock at $2-4^{\circ} \mathrm{C}$. Animals were pre-treated with 5, 10 or $20 \mathrm{mg} / \mathrm{kg}$ nortriptyline. After $4 \mathrm{hr}$ of exposure to indomethacin or cold shock, the stomach was removed for histological examinations and the levels of enzymatic and non-enzymatic oxidative stress markers were determined in the tissue samples.

Results: The results showed that nortriptyline at $20 \mathrm{mg} / \mathrm{kg}$ significantly restored the activity of the oxidative stress markers, such as Superoxide Dismutase (SOD) and Catalase (CAT) enzymes. It also decreased the tissue Malondialdehyde (MDA) concentration. In addition, nortriptyline at $20 \mathrm{mg} / \mathrm{kg}$, ameliorated the gastric tissue damages caused by indomethacin or the cold shock.

Conclusion: The results suggest that improvement in gastric mucosal lesions can be mediated by nortriptyline pretreatment, which is likely due to its antioxidant property.

Keywords: Indomethacin, Cold-shock response; Nortriptyline; Stomach; Oxidative stress

\section{Introduction}

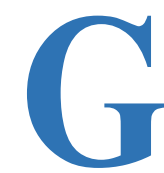

astric and duodenal ulcers are commonly known as peptic ulcers, which are defined as mucosal erosions with at least half a centimeter intrusive diameter in the human mucosa [1]. The most common complications of this disease include bleeding, perforation, and obstruction [2]. The diagnostic evaluation of bleeding in humans should be determined immediately. Endoscopic treatment, which involves injecting adrenaline, coagulating with warming probes, and cutting the bleeding vessel are recommended [3], although recurrent bleeding occurs in 10\%-20\% of the patients [4]. The administration of Proton Pump Inhibitors (PPIs), such as ranitidine hydrochloride is also help- 
ful [3]. Early clinical assessment and therapy result in reduced risk of morbidity and mortality, and the need for surgery [5]. One of the main etiologic factors in the development of chronic gastric ulcers is the consumption of Non-Steroidal Anti-Inflammatory Drugs (NSAIDs), including indomethacin, naproxen and ibuprofen $[6,7]$. Factors such as increased gastric acid, alcohol consumption, smoking, severe stress, and other chronic conditions can increase the risk of gastric mucosal ulcers [8].

The production of free radicals and induction of oxidative stress is the most prevalent mechanism involved in the gastric mucosal damage, leading to the development of gastric ulcers [9]. It is well known that indomethacin administration and cold exposure possibly increase the production of Reactive Oxygen Species (ROS), hydroxyl radicals $\left(\mathrm{HO}^{\circ}\right)$, superoxide anion radicals $\left(-\mathrm{O}^{\circ} 2\right)$, and Hydrogen Peroxide $\left(\mathrm{H}_{2} \mathrm{O}_{2}\right)$, all of which cause lipid peroxidation $[6,10]$. The evaluation of Catalase (CAT) and Superoxide Dismutase (SOD) oxidative activities, and determination of Malondialdehyde (MDA) concentration are important factors in the prediction of gastric ulcers [11-13]. These justify the popular antioxidant therapies and some herbal medicines in the management of peptic ulcers [14-16]. Various drugs, including anticholinergic agents, histamine type 2 receptor antagonists, antacids, and recently proton pump inhibitors have been developed to treat patients with peptic ulcers [17]. However, many of these agents have shown side effects.

Antipsychotics and antidepressant drugs are commonly used in the treatment of irritable bowel disease in humans [18]. The beneficial effects of antioxidants and antidepressant drugs have been reported clinically in patients with gastric ulcers [19]. Many antidepressants, e.g., fluoxetine, imipramine and its metabolite disimipramine, bupropion, amitriptyline, dothiepin, maprotiline, mianserin, trimipramine, idazoxan, and monoamine oxidase-B inhibitors have exhibited therapeutic effects in various gastric ulcer models [20-25]. Nortriptyline is a secondgeneration antidepressant that has various pharmacological properties [26]. In view of the antioxidant effects of nortriptyline and the absence of adequate studies on its pharmacological effects on gastric lesions, we investigated its therapeutic effects on the rat gastric lesions, induced either by indomethacin exposure or cold stress.

\section{Materials and Methods}

Experimental animals: Fifty male Wistar rats, weighing 180-250g were purchased from the Center of Comparative and Experimental Medicine at Shiraz University of Medical Sciences, Shiraz, Iran. The animals were adapted under $12 \mathrm{hr}$ light-dark cycle and at $23 \pm 2^{\circ} \mathrm{C}$ with free access to food and water before the experiments began. The rats were randomly divided into five groups of five each for the indomethacin-induced gastric lesion model and the same numbers were assigned to the cold stress-induced gastric lesion. The care and use of the animals were in accordance with Animal Rights Monitoring Committee Guide of Shiraz University of Medical Sciences (Protocol \#: 95-01103-11946). All animals in this study were administered their assigned agents orally. All the laboratory and histological tests were carried out in triplicate.

Indomethacin-induced Gastric Lesion Model: After 24 h of fasting, animals $(\mathrm{N}=25)$ were orally administerd as fallows: groups I, II, III were pre-treated with nortriptyline $(5,10$ or $20 \mathrm{mg} / \mathrm{kg})$. After 1 hour, they received 30 $\mathrm{mg} / \mathrm{kg}$ indomethacin (suspended in $0.5 \%$ carboxymethyl cellulose). Group IV was orally given $2.5 \mathrm{ml} / \mathrm{kg}$ normal saline $1 \mathrm{hr}$ before the administration of indomethacin (30 $\mathrm{mg} / \mathrm{kg}$ ). Group $\mathrm{V}$ was treated with $50 \mathrm{mg} / \mathrm{kg}$ ranitidine $1 \mathrm{hr}$ before taking $30 \mathrm{mg} / \mathrm{kg}$ indomethacin. Four hours after administering indomethacin, all animals were anesthetized with ether and sacrificed.

Cold Shock-induced Gastric Lesion Model: The rats $(\mathrm{N}=25)$ were kept on fasting for $24 \mathrm{hr}$. Then one hour after the oral administration of nortriptyline, normal saline or ranitidine, the rats were held in a restrainer and placed at $1-4^{\circ} \mathrm{C}$ in a refrigerator for six hours. Group I (control), received $2.5 \mathrm{ml} / \mathrm{kg}$ normal saline; groups II, III, IV were treated with 5,10 or $20 \mathrm{mg} / \mathrm{kg}$ nortriptyline, and group V was treated with $50 \mathrm{mg} / \mathrm{kg}$ ranitidine. The animals were taken out of the refrigerator after 6 hours, anesthetized with ether, and sacrificed.

Preparation of stomach tissue homogenate: The rats' stomachs that had been removed after sacrifice were incised at the great curvature, was rinsed with normal saline and photographed. The tissue samples were divided into two equal portions, one was homogenized in phosphate buffer saline (PBS; $1 / 10 \mathrm{w} / \mathrm{v} ; \mathrm{pH}=7.4$ ) and was assigned to the SOD and Catalase activities, and MDA concentration assays. The second portion was kept in $10 \%$ formalin for the histopathologic examinations.

Gastric mucosa image processing: An in-house toolbox was developed to perform the metric analysis of the wound area, based on Graphical User Interface (GUI) processing of Matlab 2012a version. The toolbox could differentiate between the wounded and normal tissue areas, based on the Red, Green And Blue (RGB) components of each pixel. Using this system, the lesions were classified as slight, moderate or severe, and the percent- 
age of the leasioned area was determined for each image. The software validity was achieved with circles subdivided into four quarters and filled with different color types. The software was able to calculate the colors for each quarter, using defined RGB values.

Lipid peroxidation assay: The MDA concentration, as a marker of lipid peroxidation, was determined as follow. A $200 \mu \mathrm{l}$ of tissue suspension was added to a mixture of the TCA $10 \%$, TBA $0.06 \%$ and the $0.5 \mathrm{ml} \mathrm{HCL} 0.5$ $\mathrm{N}$ acid, vortexed vigorously and heated in boiling water for $45 \mathrm{~min}$. After cooling, the solution was centrifuged at $1000 \mathrm{~g}$ for 10 minutes, and the absorption was read at $532 \mathrm{~nm}$. The MDA concentration was extrapolated, using a calibration curve ( $\mathrm{nM} / \mathrm{mg}$ protein) [27].

Estimation of superoxide dismutase activity: The SOD activity was assayed according to previously method described [28]. A $10 \mu \mathrm{l}$ of the homogenate was combined with 3- (4,5-dimethylthiazol-2-yl) -2,5-diphenyl tetrazolium bromide (MTT) at $1.25 \mathrm{mM}$, and pyrogallol $100 \mu \mathrm{M}$; then PBS was added to reach a final volume of $765 \mu 1$. After incubation at room temperature for 5 minutes, $0.75 \mathrm{ml}$ Dimethyl Sulfoxide (DMSO) was added to the mixture as the reaction inhibitor. The absorbance of the mixture was read at $570 \mathrm{~nm}$, and the enzyme activity was expressed on the basis of the unit. One unit is the amount of required protein in microgram to reduce the MTT to $50 \%$.

Estimation of catalase activity: The catalase activity was measured according to an established method [29]. Briefly, a solution of $\mathrm{H} 2 \mathrm{O} 2$ at $65 \mu \mathrm{M}$ was mixed with $40 \mu \mathrm{l}$ of centrifuged homogeneous supernatant of the tissue and incubated at $37^{\circ} \mathrm{C}$ for 1 minute. This was followed by adding ammonium molybdate reagent to inhibit the reaction, and the absorbance was measured at $405 \mathrm{~nm}$. The following formula was used to calculate the catalase activity:

Catalase activity $(\mathrm{Ku} / \mathrm{l})=[$ A(sample $)-$ A(blank 1$)] /$ [A (blank 2) $-A$ (blank 3) $] \times 271$

Blank 1 contained substrate, molybdate and tissue sample; Blank 2 contained substrate, molybdate and PBS; Blank 3 contained PBS, molybdate and PBS.

Assay of Tissue Protein: The Bradford method [30] was used to assay the tissue protein concentration, with bovine serum albumin as the standard.

Histopathological examinations: An intact section of the stomach tissue was used after fixation in 10\% forma- lin and processed overnight for the subsequent paraffin embedding. The samples were sectioned, molded and prepared for staining with hematoxylin and eosin [28]. The pathophysiologic alterations, such as congestion, hemorrhage, edema and erosions were microscopically examined, and a scale was assigned to each as the estimated extent of the severity of the lesions.

Statistical analyses: All values are presented as the Means \pm Standard Error of the Means (SEM). The statistical analyses were performed, using Graphpad prism, version 6 . The differences between the mean values were determined by One-way Analysis of Variance (ANOVA), and a P value of less than 0.05 was considered as statistically significant.

\section{Results}

Effect of nortriptyline on MDA level: The data showed that the MDA level in the gastric tissue of the negative control group (30 mg/kg indomethacin) was significantly higher than those groups receiving $10 \mathrm{mg} /$ $\mathrm{kg}$ or $20 \mathrm{mg} / \mathrm{kg}$ nortriptyline, and $50 \mathrm{mg} / \mathrm{kg}$ ranitidine, $(\mathrm{P}<0.001$ and $\mathrm{P}<0.0001$, respectively). In the treatment groups receiving $5 \mathrm{mg} / \mathrm{kg}$ nortriptyline, there was no significant changes compared to those in the control group (30 $\mathrm{mg} / \mathrm{kg}$ indomethacin) (Figure 1A). Similarly, the group reciving ranitidine hydrochloride showed a significant decrease in the MDA content compared to those receiving $5 \mathrm{mg} / \mathrm{kg}$ or $10 \mathrm{mg} / \mathrm{kg}$ nortriptyline, $(\mathrm{P}<0.0001$ $\& \mathrm{P}<0.01$, respectively). Figure $2 \mathrm{~A}$ shows that the coldshock-induced gastric lesions in rats (controls) caused a significant increase in the MDA level compared to the groups receiving 10 or $20 \mathrm{mg} / \mathrm{kg}$ nortriptyline $(\mathrm{P}<0.01$ $\& \mathrm{P}<0.001$, respectively), and the group receiving 50 $\mathrm{mg} / \mathrm{kg}$ ranitidine $(\mathrm{P}<0 / 001)$. However, a significant decrease in MDA was observed in the ranitidine and nortriptyline $(20 \mathrm{mg} / \mathrm{kg})$ groups, compared to the control group $(\mathrm{P}<0.01)$.

Effect of nortriptyline on SOD: In the groups pretreated with nortriptyline at 5,10 or $20 \mathrm{mg} / \mathrm{kg}(\mathrm{P}<0.01$, $(\mathrm{P}<0.001 \& \mathrm{P}<0.0001$, respectively), and ranitidine as positive control $(\mathrm{P}<0.001)$, the SOD activity was significantly higher than that of the $30 \mathrm{mg} / \mathrm{kg}$ indomethacin group. However, there was no significant difference between the groups receiving nortriptyline and ranitidine (Figure 1B). Pretreatment with 10 or $20 \mathrm{mg} / \mathrm{kg}$, but not $5 \mathrm{mg} / \mathrm{kg}$ nortriptyline doses, and ranitidine one hour before the onset of cold-shock expousure led to a significant increase in the SOD activity compared to the group reciving nomal saline $(\mathrm{P}<0.001)$. Similarly as shown in Figure $2 \mathrm{~B}$, in the groups that received $20 \mathrm{mg} / \mathrm{kg}$ nor- 
Table 1. Effects of nortriptyline and ranitidine on indomethacin-induced gastric ulcers' percent area in rats

\begin{tabular}{ccccc}
\hline PuorG & Normal & Mild Lesion & Moderate Lesion & Sever Lesion \\
\hline Control & $42.49 \pm 3.5$ & $54.43 \pm 7.1$ & $2.22 \pm 3.4$ & $0.56 \pm 0.5$ \\
\hline Nort $5 \mathrm{mg}$ & $62.71 \pm 4.0$ & $37.01 \pm 3.9$ & $0.26 \pm 0.3$ & $0.01 \pm 0$ \\
\hline Nort 10 mg & $79.72 \pm 3.8$ & $19.14 \pm 2.9$ & $1.10 \pm 0.9$ & $0.02 \pm 0$ \\
\hline Nort 20 mg & $83.05 \pm 5.0$ & $16.94 \pm 5.0$ & 0 & 0 \\
\hline Ranitidine & $75.86 \pm 18.9$ & $24.12 \pm 18.9$ & 0 & 0 \\
\hline
\end{tabular}

Nort: Nortriptyline

Table 2. Nortriptyline and Ranitidine effects on cold-shock responses of gastric ulcers' percent area in rats

\begin{tabular}{ccccc}
\hline Group & Normal & Mild Lesion & Moderate Lesion & Sever Lesion \\
\hline Control & $40.54 \pm 11.9$ & $54.81 \pm 11.9$ & $4.1 \pm 2.7$ & $0.53 \pm 0.4$ \\
\hline Nort $5 \mathrm{mg}$ & $42.1 \pm 8.1$ & $55.78 \pm 7.5$ & $2.14 \pm 2.1$ & 0 \\
\hline Nort $10 \mathrm{mg}$ & $45.89 \pm 1.5$ & $44.75 \pm 10.6$ & $9.38 \pm 9.4$ & 0 \\
\hline Nort $20 \mathrm{mg}$ & $84.48 \pm 6.2$ & $14.54 \pm 5.1$ & $1 \pm 1$ & 0 \\
\hline Ranitidine & $73.62 \pm 5.1$ & $26.38 \pm 5.1$ & 0 & 0 \\
\hline
\end{tabular}

Nor: MNortriptyline

triptyline and ranitidine, the SOD activity significantly increased compared to those that recieved $5 \mathrm{mg} / \mathrm{kg}$ nortriptyline $(\mathrm{P}<0.05)$

Effect of nortriptyline on catalase activity: Treatment with $20 \mathrm{mg} / \mathrm{kg}$ but not 5 or $10 \mathrm{mg} / \mathrm{kg}$ nortriptyline and ranitidine $(\mathrm{P}<0.05 \& \mathrm{P}<0.01$, respectively), prior to receiving indomethacin, significantly increased the catalase activity compared to those that received normal saline. The catalase activity at $20 \mathrm{mg} / \mathrm{kg}$ nortriptyline was significantly increased compared to the group that received $5 \mathrm{mg} / \mathrm{kg}$ of the same drug $(\mathrm{P}<0.05$; Figure $1 \mathrm{C})$. The results shown in Figure $2 \mathrm{C}$ indicated that the catalase activity in the group pre-treated with $20 \mathrm{mg} / \mathrm{kg}$ nortriptyline and ranitidine one hour before expousure to cold-shock was significantly higher than that of the group reciving normal saline $(\mathrm{P}<0.01)$. The group that received $20 \mathrm{mg} / \mathrm{kg}$ nortriptyline also showed a significant increase in the catalase activity compared to the group receiving $5 \mathrm{mg} / \mathrm{kg}$ nortriptyline $(\mathrm{P}<0.05)$.

Histological evaluation of the nrtriptyline effects: Results of the microscopic examinations from the control group (normal saline) showed high degrees of hyperemia and edema in the rats' gastric tissue samples. However, in the groups administered 5 or $10 \mathrm{mg} / \mathrm{kg}$

A
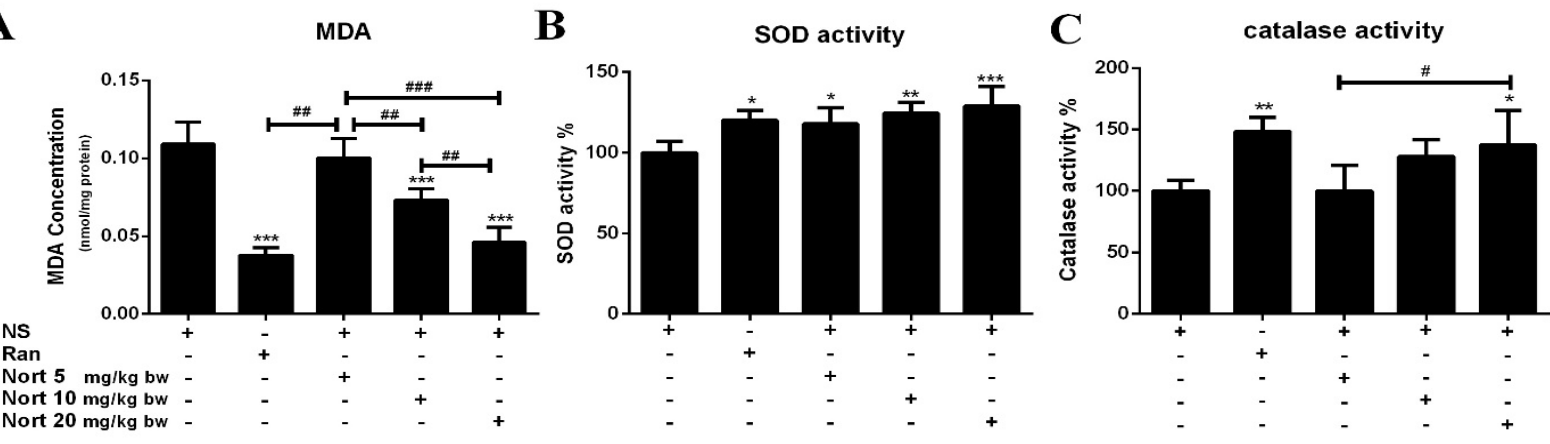

Figure 1. Effects of nortriptyline

A: MDA; B: SOD; and C: CAT activities in the stomach tissues of rats given indomethacin;

${ }^{*} \mathrm{P}<0.05$ vs. respective control; ${ }^{*} \mathrm{P}<0.05$ vs. respective drug treatment; Crl: Control, From left to right; NS: Normal saline; Ran: Ranitidine, $50 \mathrm{mg} / \mathrm{kg}$; Nort: Nortriptyline $(5,10$ or $20 \mathrm{mg} / \mathrm{kg})$ 
A

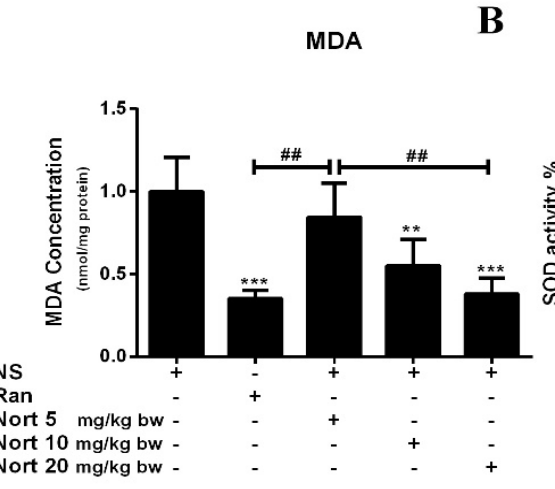

B

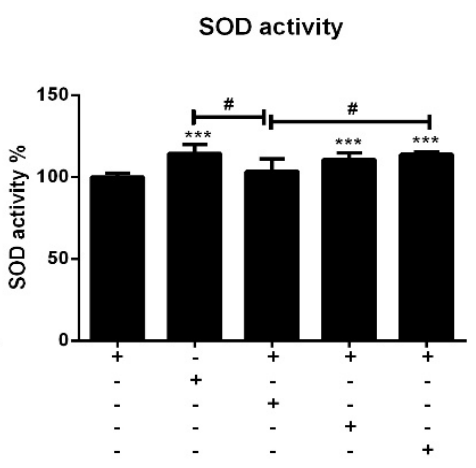

C

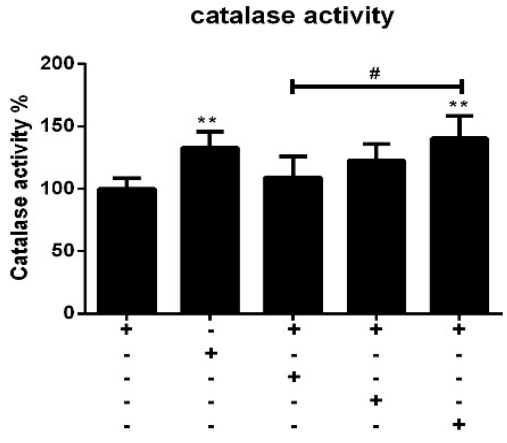

Figure 2. Effects of nortriptyline

A: MDA; B: SOD; and C: CAT on the stomach tissues of the rats exposed to cold stress;

* $\mathrm{P}<0.05$ vs. respective control; ${ }^{\#} \mathrm{P}<0.05$ vs. respective drug treatment; $\mathrm{Crl}$ : control;

From left to right: NS: Normal saline; Ran: Ranitidine, 50mg/kg; Nort: Nortriptyline (5, 10 or 20 mg/kg)

nortriptyline, high degrees of the submucosal edema and hyperemia, and a moderate degree of inflammatory cells infiltration into the indomethacin-induced gastric lesions were observed. However, a pre-treatment with $20 \mathrm{mg} /$ $\mathrm{kg}$ nortriptyline resulted in much less edema and hyperemia (Figure 3). As shown in Figure 4, gastric tissues of the rats pretreated with normal saline, or with 5 or $10 \mathrm{mg} / \mathrm{kg}$ nortriptyline in the cold-shock-induced gastric lesions showed much hyperemia. There was only slight edema in the gastric tissue of the rats receiving $20 \mathrm{mg} /$ $\mathrm{kg}$ nortriptyline and exposed to the cold stress. However, the treatment group receiving ranitidine showed no microscopic and morphological changes.

Image processing: As shown in the indomethacin model (Table 1), the percentages of mild, moderate and severe tissue lesions in the normal saline group were $54 \%, 2 \%$ and $1 \%$, respectively. Approximately, $76 \%$ of the tissue were normal in the rats treated by ranitidine. In addition, the results indicated that $62 \%$ of the normal tissue and $37 \%$ of the mild grade lesions belonged to the gastric tissues of the rats pretreated with $5 \mathrm{mg} / \mathrm{kg}$ nortriptyline. There was no significant number of moderate or
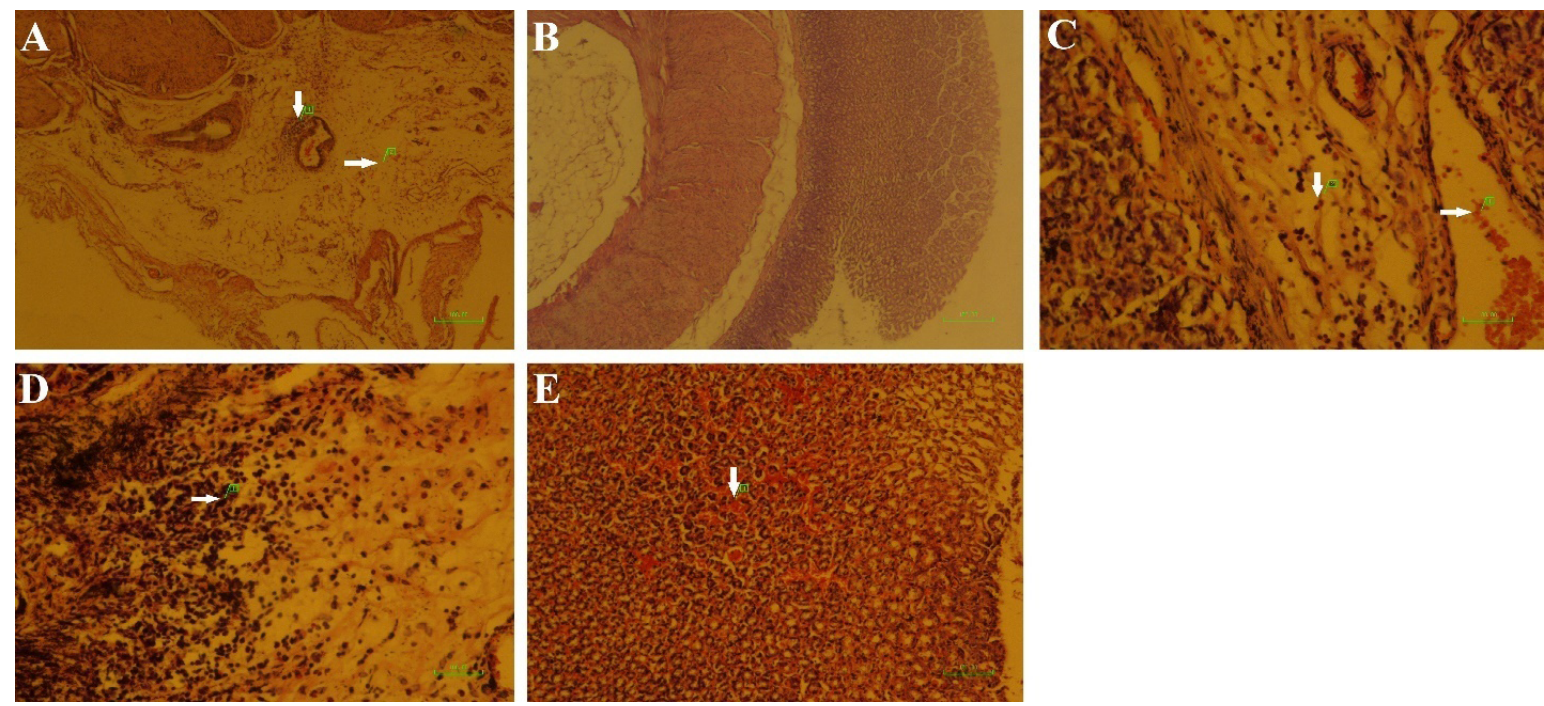

Figure 3. Photomicrographs of $\mathrm{H} \& \mathrm{E}$ staining of the gastric mucosa (magnification $\times 100$ )

A: The control group, showing a high level of hyperemia; B: Ranitidine $(50 \mathrm{mg} / \mathrm{kg})$ group, showing normal gastric mucosa; C \& D: Nortriptyline ( 5 or $10 \mathrm{mg} / \mathrm{kg}$, oral) groups, showing high levels of hyperemia, edema and inflammatory cells infiltration into the gastric mucosa and submucosa; E: Nortriptyline $(20 \mathrm{mg} / \mathrm{kg}$, oral $)$ group, showing few areas of gastric edema and hyperemia 

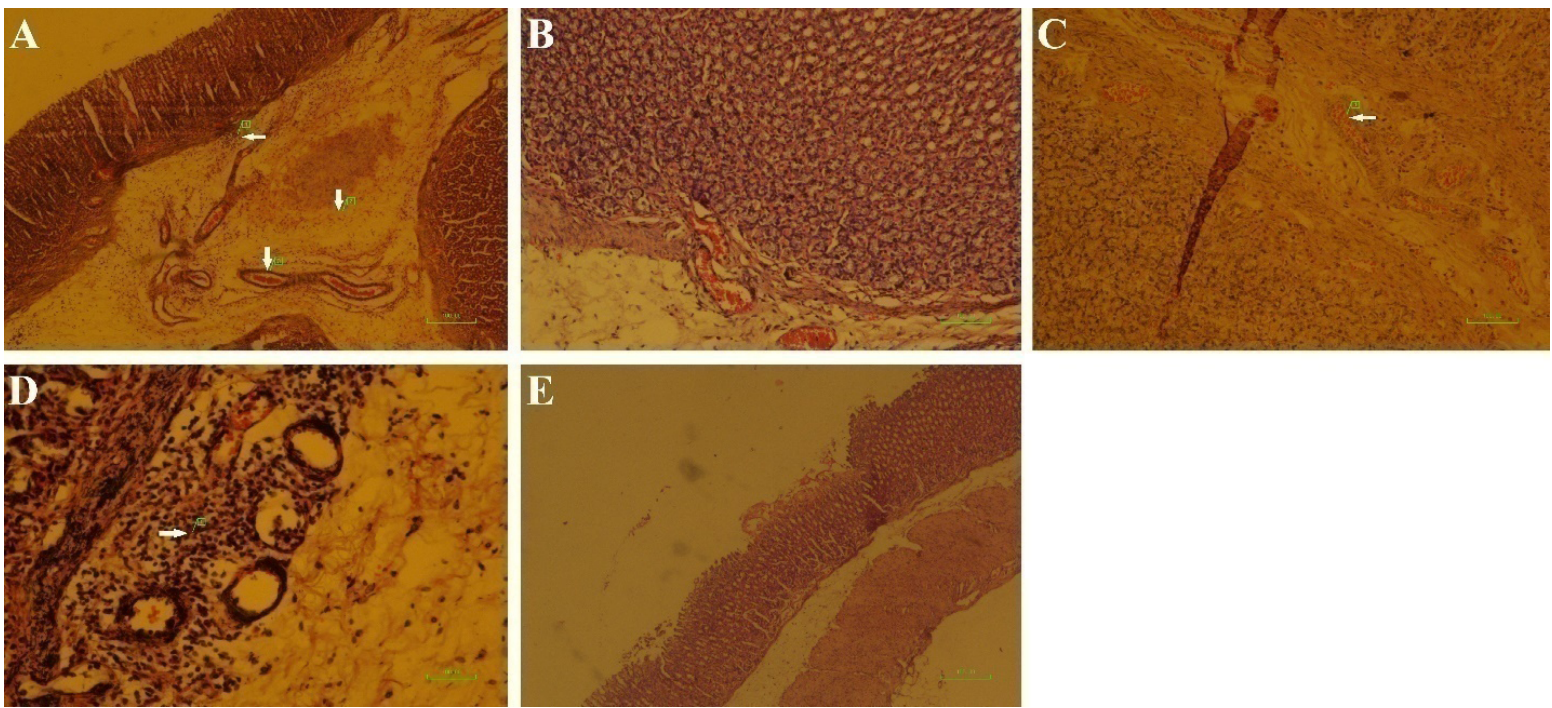

Figure 4. Photomicrographs of H\&E staining of gastric mucosa (magnification $\times 100$ )

A: The control group, showing high levels of hyperemia and edema; B: Ranitidine ( $50 \mathrm{mg} / \mathrm{kg})$ group, showing normal gastric mucosa; C \& D: Nortriptyline (5 or 10mg/ kg, oral) groups, showing a high level of hyperemia; E: Nortriptyline $(20 \mathrm{mg} / \mathrm{kg}$ oral) group; showing very little microscopic and morphological changes

severe grade tissue lesions in these animals. Finally, a significantly greater amounts of normal tissue was observed in groups pretreated with nortriptyline at 10 or $20 \mathrm{mg} / \mathrm{kg}$, compared to those with $5 \mathrm{mg} / \mathrm{kg}$. Table 2 shows that $55 \%$ of the lesions in rats given normal saline were assessed as mild grade in the cold stress model. While there were moderate level lesions in the positive control group of ranitidine, $74 \%$ of the tissue was normal. In the rats treated with $5 \mathrm{mg} / \mathrm{kg}$ nortriptyline, mild tissue lesions were present in $56 \%$ of them, but no severe lesion was observed. The stomach tissue samples of the rats pretreated with 10 $\mathrm{mg} / \mathrm{kg}$ nortriptyline showed mild lesions in $45 \%$ of the samples. Also, $85 \%$ of all of the gastric tissue samples in the rats that received $20 \mathrm{mg} / \mathrm{kg}$ nortriptyline were histologically diagnosed as normal, with the remaining $15 \%$ showing few spots of mild lesions.

\section{Discussion}

Studies have reported that Nonsteroidal Anti-Inflammatory Drugs (NSAID), Helicobacter pylori infection and oxidative stressors are important causes of gastric lesions [31-33]. The protective effects of anti-depressant drugs against gastric ulcers is believed to stem from the inhibition of histamine and leukotriene release, and acid secretion from the gastric mucosa [23]. Tissue hypoxemia and oxidative stress are the causes of gastric ulcer pathogenesis, secondary to the accumulation of ROS. It caninterrupt the macromolecules, including proteins, DNA and lipids, and cellular structures, leading to injuries and cell death [34]. In this study, the enzymatic and non-enzymatic antioxidant defense in the gastric mucosa against ROS generation and development of lesions were evaluated histopathologically and biochemically.

We selected the nortriptyline doses based on the prescribed dosage for humans, which has shown therapeutic benefits without causing adverse effects [35]. Also, there was no adverse effects or death documented in the rats. In addition, the acute toxic dose (LD50) of nortriptyline in rats has been $502 \mathrm{mg} / \mathrm{kg}$ orally; $22.3 \mathrm{mg} / \mathrm{kg}$ intravenously, and $666 \mathrm{mg} / \mathrm{kg}$ subcutaneously [36]. Consistently, the rats that were exposed to both lesion-inducing models in this study developed tissue edema and hyperemia. These findings are similar to those reported by Ahmad et al. [37]. Also, we demonstrated that pretreatment with nortriptyline increased the catalase and SOD activities in addition to reducing the MDA level. The latter is a well-known oxidative marker for gastric tissue lesions induced by indomethacin and cold stress exposure in a dose dependent manner.

The SOD catalyzes the anion superoxide (-O2) into oxygen and hydrogen peroxide. The remarkable improvements observed in the CAT and SOD activities may be interpreted as the nortriptyline effect against ROS. Also, inhibition of MDA, and increases in SOD and CAT activities collectively are gastric mucosa protective mechanisms against the excessive ROS generation [38].

Although the mechanism of nortriptyline action in the treatment of gastric lesions is not well understood, indomethacin significantly decreases the levels of glutathione 
[39], Glutathione Peroxidase (GPx) and SOD, while increases the hydrogen peroxide and hydroxyl ions, which are the oxidative causes of gastric mucosa lesions [15]. The increase in the antioxidant catalase seems to be the mechanism by which nortriptyline interrupts the hydrogen peroxide breakdown and prevents tissue damages to gastric mucosa. Zhang et al. [40] reported that nortriptyline is neuroprotective against cerebral ischemia, which correlates well with its inhibitory effect on mitochondrial destruction and caspase activation [40]. Another study demonstrated that nortriptyline increases the activities of catalase and SOD while reduces the MDA levels in rats' testicular tissue lesions [41].

El-awdan, et al. [42] demonstrated that three antidepressants, including mirtazapine, citalopram, and venlafaxine reduced the MDA, TNF- $\alpha$ and NO levels, leading to an increase in the glutathione peroxidase activity and eventually improved the indomethacin induced-gastric lesions in depressed rats [42]. Moreover, tricyclic antidepressants are competitive antagonists of muscarinic receptors, resulting in reduced gastric mucous secretion and enhanced the healing of mucosal lesions [43-45]. While nortriptyline decresed MDA levels and increased the antioxidant enzymes, its reduction of the gastric lesions was of clinical significance. The scores for the ulcerated areas were confirmed by the considerable effects on microscopic indices of pathologic alterations. These included hyperemia, edema, inflammatory cells infiltration into the stomach mucosa and submucosa, secondary to the indomethacin administration or cold stress exposure of the rats' stomach tissue. Finally, the current study findings support those of a previous study, suggesting that antidepressants may be more effective than the common ulcer reducing drugs, such as antacids and $\mathrm{H} 2$ receptor blockers in the treatment of stress-induced gastric ulcers [46].

Limitations of the Study: We assesed MDA concentration and the SOD and Catalase activities, representing oxidative stress. To confirm our results and to determine the mechanism of protective effect of nortriptyline against gastric lesions, measuring the mRNA and protein expression levels of SOD and catalase activities could have been informative; however, we did not have the facilities.

Recommendations for Future Studies: Measuring the Glutathione and ROS levels, and the related signal transduction pathways would be a choice method to explore the mechanism of nortriptyline action against tissue oxidation. Evaluation of the protective effect of another members of TCA drugs is also recommended.

\section{Conclusions}

The results of this study suggest that nortriptyline is effective in the management of stress-induced gastric ulcers, and it may exert its protective effects through the inhibition of oxidative stress and antioxidant enzyme pathways in the rats' gastric tissue. The molecular mechanisms of nortriptyline action that inhibited the development of gastric ulcers awaits future research.

\section{Ethical Considerations}

\section{Compliance with ethical guidelines}

We received the Ethical approval and observed the respective guidelines set by the Ethics Committee of Shiraz University of Medical Sciences (Ethics Code: IR.SUMS. REC.1395.S680).

\section{Funding}

This work was supported by a Research Grants Provided by Shiraz University of Medical Sciences, Shiraz, Iran (Grant No.: 95-01-103-11946).

\section{Author's contributions}

Conceptualization: Mohammad Javad Khoshnoud, Marzieh Rashedinia, Majid Keshavarzi; Writing-original draft \& methodology: All author; Writing-review \& editing: Majid Keshavarzi, Marzieh Rashedinia; Funding acquisition: Mohammad Javad Khoshnoud; Supervision: Mohammad Javad Khoshnoud, \& Marzieh Rashedinia.

\section{Conflict of interest}

The authors declare no conflicts of interests with any internal and external entity.

\section{Acknowledgements}

The authors acknowledge the support of the Research Deputy of Shiraz University of Medical Sciences toward this study. The authors also wish to thank Dr. Nasrin Shokrpour at the Research Consultation Center, Shiraz University of Medical Sciences, for her invaluable assistance with the review and editing of the first draft of the manuscript. 


\section{References}

[1] Prabhu V, Shivani A. An overview of history, pathogenesis and treatment of perforated peptic ulcer disease with evaluation of prognostic scoring in adults. Ann Med Health Sci Res. 2014 4(1):22-9. [DOI:10.4103/2141-9248.126604] [PMID] [PMCID]

[2] Milosavljevic T, Kostić-Milosavljević M, Jovanović I, Krstić M. Complications of peptic ulcer disease. Dig Dis. 2011; 29(5):491-3. [DOI:10.1159/000331517] [PMID]

[3] Shao J, Gumz ML, Cain BD, Xia SL, Shull GE, van Driel IR, et al. Pharmacological profiles of the murine gastric and colonic $\mathrm{H}, \mathrm{K}-$ ATPases. Biochim Biophys Acta Gen Subj. 2010; 1800(9):906-11. [DOI:10.1016/j.bbagen.2010.05.002] [PMID] [PMCID]

[4] Wilkins T, Khan N, Nabh A, Schade RR. Diagnosis and management of upper gastrointestinal bleeding. Am Fam Physician. 2012; 85(5):469-76. [PMID]

[5] Aabakken L. Current endoscopic and pharmacological therapy of peptic ulcer bleeding. Best Pract Res Clin Gastroenterol. 2008; 22(2):243-59. [DOI:10.1016/j.bpg.2007.10.010] [PMID]

[6] Atalay F, Odabasoglu F, Halici M, Cakir A, Cadirci E, Aslan A, et al. Gastroprotective and antioxidant effects of Lobaria pulmonaria and its metabolite rhizonyl alcohol on indomethacin-induced gastric ulcer. Chem Biodivers. 2015; 12(11):1756-67. [DOI:10.1002/cbdv.201400432] [PMID]

[7] Chatterjee S, Chatterjee A, Roy S, Bera B, Bandyopadhyay SK. L-Theanine healed NSAID-induced gastric ulcer by modulating pro/antioxidant balance in gastric ulcer margin. J Nat Med. 2014; 68(4):699-708. [DOI:10.1007/s11418-014-0852-x] [PMID]

[8] Chan FK, Ching JYL, Suen BY, Tse YK, Wu JCY, Sung JJY. Effects of Helicobacter pylori infection on long-term risk of peptic ulcer bleeding in low-dose aspirin users. Gastroenterology. 2013; 144(3):528-35. [DOI:10.1053/j.gastro.2012.12.038] [PMID]

[9] Tandon R, Khanna HD, Dorababu M, Goel RK. Oxidative stress and antioxidants status in peptic ulcer and gastric carcinoma. Indian J Physiol Pharmacol. 2004; 48(1):115-8. [PMID]

[10] Şahin E, Gümüşlü S. Cold-stress-induced modulation of antioxidant defence: Role of stressed conditions in tissue injury followed by protein oxidation and lipid peroxidation. Int J Biometeorol. 2004; 48(4):165-71. [DOI:10.1007/s00484-004-0205-7] [PMID]

[11] El-Missiry MA, El-Sayed IH, Othman AI. Protection by metal complexes with SOD-mimetic activity against oxidative gastric injury induced by indomethacin and ethanol in rats. Ann Clin Biochem. 2001; 38(Pt 6):694-700. [DOI:10.1258/0004563011900911] [PMID]

[12] Majumdar B, Ray Chaudhuri SG, Ray A, Bandyopadhyay SK. Effect of ethanol extract of Piper betle Linn leaf on healing of NSAID-induced experimental ulcer--A novel role of free radical scavenging action. Indian J Exp Biol. 2003; 41(4):311-5. [PMID]

[13] Lutnicki K, Szpringer E, Czerny K, Ledwozyw A. Effects of ethanol and arachidonic acid pathway inhibitors on the effectiveness of gastric mucosa cytoprotection. Folia Morphol (Warsz). 2001; 60(1):47-56. [PMID]

[14] Levine JE, Leontiadis GI, Sharma VK, Howden CW. Metaanalysis: The efficacy of intravenous $\mathrm{H} 2$-receptor antagonists in bleeding peptic ulcer. Aliment Pharmacol Ther. 2002; 16(6):113742. [DOI:10.1046/j.1365-2036.2002.01274.x] [PMID]
[15] Odabasoglu F, Cakir A, Suleyman H, Aslan A, Bayir Y, Halici $\mathrm{M}$, et al. Gastroprotective and antioxidant effects of usnic acid on indomethacin-induced gastric ulcer in rats. J Ethnopharmacol. 2006; 103(1):59-65. [DOI:10.1016/j.jep.2005.06.043] [PMID]

[16] Langmead L, Rampton DS. Review article: Herbal treatment in gastrointestinal and liver disease-benefits and dangers. Aliment Pharmacol Ther. 2001; 15(9):1239-52. [DOI:10.1046/j.13652036.2001.01053.x] [PMID]

[17] Willemijntje AH, Pankaj JP. Agents used for control of gastric acidity and treatment of peptic ulcers and gastroesophageal reflux disease. In: Joel GH and Lee EL, Editors. The Pharmacological Basis of Therapeutics. Holtzbrinck Publishing Group: DescriptionMacmillan; 2001.

[18] Talley NJ. Antidepressants in IBS: Are we deluding ourselves? Am J Gastroenterol. 2004; 99(5):921-3. [DOI:10.1111/j.15720241.2004.04128.x] [PMID]

[19] Sen T, Abdulsalam CA, Pal S, Sen S, Karmakar S, Saravanan $\mathrm{KS}$, et al. Effect of amitriptyline on gastric ulceration. Fundam Clin Pharmacol. 2002; 16(4):311-5. [DOI:10.1046/j.14728206.2002.00092.x] [PMID]

[20] Hernandez DE, Xue BG. Imipramine prevents stress gastric glandular lesions in rats. Neurosci Lett. 1989; 103(2):209-12. [DOI:10.1016/0304-3940(89)90577-6]

[21] Tobe A, Yoshida Y, Egawa M. The influence of 2-(4-methylaminobutoxy) diphenylmethane hydrochloride (MCI-2016) on gastric ulcer and gastric acid secretion. Arzneimittelforschung. 1983; 33(3):397-400. [PMID]

[22] Paré WP, Redei E. Depressive behavior and stress ulcer in Wistar Kyoto rats. J Physiol Paris. 1993; 87(4):229-38. [DOI:10.1016/0928-4257(93)90010-Q]

[23] Hano J, Bugajski J, Wantuch C. The effect of drugs interfering with biogenic amines metabolism on gastric secretion and reserpine-ulcers development in rats. Pol J Pharmacol Pharm. 1978; 30(4):501-11. [PMID]

[24] Gabry K, Chrousos GP, Rice KC, Mostafa RM, Sternberg E, Negrao $\mathrm{AB}$, et al. Marked suppression of gastric ulcerogenesis and intestinal responses to stress by a novel class of drugs. Mol Psychiatry. 2002; 7(5):474-83. [DOI:10.1038/sj.mp.4001031] [PMID]

[25] Utkan T, Ulak G, Gökalp Yildiran H, Yardemoglu M, Nejat Gacar M. Investigation on the mechanism involved in the effects of agmatine on ethanol-induced gastric mucosal injury in rats. Life Sci. 2000; 66(18):1705-11. [DOI:10.1016/S00243205(00)00493-8]

[26] Clouse RE. Antidepressants for irritable bowel syndrome. Gut. 2003; 52(4):598-9. [DOI:10.1136/gut.52.4.598] [PMID] [PMCID]

[27] Khoshnoud MJ, Siavashpour A, Bakhshizadeh M, Rashedinia M. Effects of sodium benzoate, a commonly used food preservative, on learning, memory, and oxidative stress in brain of mice. J Biochem Mol Toxicol. 2018; 32(2):e22022. [DOI:10.1002/ jbt.22022] [PMID]

[28] Sabahi Z, Khoshnoud MJ, Khalvati B, Hashemi SS, Farsani ZG Gerashi HM, et al. Syringic acid improves oxidative stress and mitochondrial biogenesis in the liver of streptozotocin-induced diabetic rats. Asian Pac J Trop Biomed. 2020; 10(3):111.

[29] Góth L. A simple method for determination of serum catalase activity and revision of reference range. Clin Chim Acta. 1991; 196(2-3):143-51. [DOI:10.1016/0009-8981(91)90067-M] 
[30] Bradford MM. A rapid and sensitive method for the quantitation of microgram quantities of protein utilizing the principle of protein-dye binding. Anal Biochem. 1976; 72(1-2):248-54. [DOI:10.1016/0003-2697(76)90527-3]

[31] Carleton HM, Drury RAB, Wallington EA. Carleton's histological technique. Oxford: Oxford University Press; 1980. https:// books.google.com/books?id=4-dqAAAAMAAJ\&dq

[32] Graham DY. History of Helicobacter pylori, duodenal ulcer, gastric ulcer and gastric cancer. World J Gastroenterol. 2014; 20(18):5191-204. [DOI:10.3748/wjg.v20.i18.5191] [PMID] [PMCID]

[33] Friendship RM. Gastric ulceration in swine. J Swine Health Prod. 2004; 12(1):34-5. https://www.aasv.org/shap/issues/ v12n1/v12n1p34.html

[34] Rosenstock S, Jørgensen T, Bonnevie O, Andersen L. Risk factors for peptic ulcer disease: A population based prospective cohort study comprising 2416 Danish adults. Gut. 2003; 52(2):18693. [DOI:10.1136/gut.52.2.186] [PMID] [PMCID]

[35] Woolf AD, Erdman AR, Nelson LS, Martin Caravati E Cobaugh DJ, Booze LL, et al. Tricyclic antidepressant poisoning: An evidence-based consensus guideline for outof-hospital management. Clin Toxicol. 2007; 45(3):203-33. [DOI:10.1080/15563650701226192] [PMID]

[36] Meyers DB, Small RM, Anderson RC. Toxicology of nortriptyline hydrochloride. Toxicol Appl Pharmacol. 1966; 9(1):152-9. [DOI:10.1016/0041-008X(66)90039-1]

[37] Ahmad SS, Najmi AK, Kaundal M, Akhtar M. Gastroprotective effect of Thymoquinone on water immersion restraint stress induced ulceration in rats. Drug Res. 2017; 67(06):366-72. [DOI:10.1055/s-0043-103574] [PMID]

[38] Radi R. Oxygen radicals, nitric oxide, and peroxynitrite: Redox pathways in molecular medicine. Proc Nat Acad Sci U S A. 2018; 115(23):5839-48. [DOI:10.1073/pnas.1804932115] [PMID] [PMCID]

[39] Munji RN, Choe Y, Li G, Siegenthaler JA, Pleasure SJ. Wnt signaling regulates neuronal differentiation of cortical intermediate progenitors. J Neurosci. 2011; 31(5):1676-87. [DOI:10.1523/ JNEUROSCI.5404-10.2011] [PMID] [PMCID]

[40] Zhang WH, Wang H, Wang X, Narayanan MV, Stavrovskaya IG, Kristal BS, et al. Nortriptyline protects mitochondria and reduces cerebral ischemia/hypoxia injury. Stroke. 2008; 39(2):45562. [DOI:10.1161/STROKEAHA.107.496810] [PMID] [PMCID]

[41] Yazdani I, Ghazi-Khansari M, Saeedi Saravi SS, Nobakht N, Majdani R, Rezayat SM, et al. Nortriptyline protects testes against germ cell apoptosis and oxidative stress induced by testicular ischaemia/reperfusion. Andrologia. 2017; 49(2):e12605. [DOI:10.1111/and.12605] [PMID]

[42] El-Awdan SA, Zaki HF. Gastroprotective activity of mirtazapine, escitalopram and venlafaxine in depressed rats. Afr J Pharm Pharmacol. 2013; 7(40):2701-9. [DOI:10.5897/AJPP2013.3840]

[43] Snyder SH, Yamamura HI. Antidepressants and the muscarinic acetylcholine receptor. Arch Gen Psychiatry. 1977; 34(2):236-9. [DOI:10.1001/archpsyc.1977.01770140126014] [PMID]

[44] Clemmesen L. Anticholinergic side-effects of antidepressants: Studies of the inhibition of salivation. Acta Psychiatr Scand. 1988; 78(S345):90-3. [DOI:10.1111/j.1600-0447.1988.tb08574.x] [PMID]
[45] Khawam EA, Laurencic G, Malone Jr DA. Side effects of antidepressants: An overview. Cleve Clin J Med. 2006; 73(4):356-61. [DOI:10.3949/ccjm.73.4.351] [PMID]

[46] Elsaed WM, Alahmadi AM, Al-Ahmadi BT, Taha JA, Tarabishi RM. Gastroprotective and antioxidant effects of fluvoxamine on stress-induced peptic ulcer in rats. J Taibah Univ Med Sci. 2018; 13(5):422-31. [DOI:10.1016/j. jtumed.2018.04.010] [PMID] [PMCID] 
This Page Intentionally Left Blank 